\title{
Parameters of hardened concrete with the addition of metakaolin
}

\author{
Anna Kotwa* \\ Kielce University of Technology, Al. Tysiąclecia PP 7, 25-314 Kielce, Poland
}

\begin{abstract}
There is currently no known one recipe for a concrete mix that would be suitable in all operating conditions. At present, in addition to the basic ingredients, mineral additives and chemical admixtures can be found in the formulas of concrete mixes. Each intentionally introduced addition to the concrete mix affects the rheological characteristics of the concrete mix as well as the parameters of hardened concrete. The use of mineral additives replacing cement and aggregate in a concrete mix should contribute to environmental protection in a simple and economical way. If, in addition, additives are by-products of industry, they should be managed. Alternatively, one should look for possibilities of their neutralization, eg in the concrete industry. The article applies to laboratory tests of concretes with the addition of $0 \%, 10 \%, 20 \%, 30 \%$ metakaolin. The additive was replaced with cement in a concrete mix. The effect of the additive on compressive strength, water absorption and capillary rupture of concretes was investigated. Compressive strength was tested after 14, 28, 56 and 90 days. Water absorption and capillary rupture was tested after 28, 56 and 90 days.
\end{abstract}

\section{Introduction}

PN-EN 206:2014 Concrete - Requirements, properties, production and compliance [1] defines the concept of addition to concrete as fine-grained material used to improve selected properties of fresh concrete mix and / or parameters of hardened concrete. The standard distinguishes between two types of additives: type I - almost inert additives, and type II additives with pozzolanic properties or latent hydraulic properties. Usually added in excess of $5 \%$ by weight of cement. They are most often used as cement substitutes in appropriate proportions. Proper selection of additives positively affects the rheological characteristics and parameters of hardened concretes during a longer period of maturation. Additives have already become an integral component of concrete mixes. As additives to concrete, natural materials, industrial waste, by-products from various industries or other materials are used, the production of which consumes less energy than the production of cement, [2]. In recent years, there has been an increasing interest of scientists in using calcined clay in the form of metakaolin as pozzolanic mortar and concrete mixes. Metakaolin is natural, fine-grained ( $99.9 \%$ of grains have a size below $16 \mu \mathrm{m}$, their average size is $3 \mu \mathrm{m}$ ) [3] filler added to concrete mixes and mortars. Metakaolin is a mineral that is formed in the process of

\footnotetext{
* Corresponding author: a.ceglarska@tu.kielce.pl
} 
dehydration at $700-800^{\circ} \mathrm{C}$ of natural kaolinite. The agent is mainly used, due to the ability to bind calcium hydroxide $(\mathrm{CH})$, which is partly responsible for reducing the durability of concrete. Reducing the content of calcium hydroxide improves the concrete's resistance to sulfate aggression and the aggression of alkali-aggregate and improves the increase in compressive strength [4]. Metakaolinite contains reactive silicates and aluminates $\left(\mathrm{AS}_{2}\right)$, which in the presence of water react with $\mathrm{CH}$ portlandite being a cement hydration product, resulting in the $\mathrm{C}-\mathrm{S}-\mathrm{H}$ gel phase and aluminum-containing crystalline phases, such as $\mathrm{C}_{4} \mathrm{AH}_{13}, \mathrm{C}_{2} \mathrm{ASH}_{8}$ and $\mathrm{C}_{3} \mathrm{AH}_{6}[5,6]$. Such a reaction proceeds quickly and after about 3 days you can see the presence of these phases. The addition of metakaolin reduces the workability of the fresh concrete mix. This forces the necessity of using a superplasticizer to achieve a comparable degree of liquidity of concrete mixes with a variable amount of additive in its composition. The improvement of selected parameters of hardened concrete depends on the amount of cement replaced with the addition of metakaolin. The additive allows the improvement of selected mechanical parameters of cement composites. In the literature one can find the results of laboratory tests confirming that the replacement of cement with $15 \%$ metakaolinite as a cement substitute resulted in an increase in compressive strength, lower water absorption and decrease in capillary rising compared to reference concrete $[7,8]$.

Metakaolin is an industrial product, the production of which, however, is friendlier to the environment than the production of cement due to the lower process temperature and lower $\mathrm{CO}_{2}$ emission to the atmosphere [9]. Producing one ton of metakaolin absorbs about $80 \%$ less energy than producing the same amount of cement [10].

In the planned laboratory tests, the impact of replacing cement with metakaolin addition in the amount of $0 \%, 10 \%, 20 \%, 30 \%$ on the mechanical properties of hardened concrete, ie on the change of compressive strength, absorbability, capillary rise, will be analyzed.

\section{Laboratory tests}

CEM I 42.5 R was used in the tests in accordance with PN-EN 197-1: 2012 [11]. Cement properties are presented in table 1, while table 2 contains metakaolin parameters. Four series of concrete mixtures with a constant $\mathrm{w} / \mathrm{s}$ ratio $=0.41$ were made. Cement in concrete mixtures was replaced by the addition of metakaolin in variable proportions of $0 \%, 10 \%$, $20 \%, 30 \%$. Dolomite aggregate from the Górno mine and quartz sand with a grain size of $1 \mathrm{~mm}$ were used.

Table 1. Basic properties of cement CEM I 42,5R.

\begin{tabular}{|c|c|r|r|r|r|r|r|c|c|}
\hline \multirow{2}{*}{ Lp. } & \multirow{2}{*}{ Cement } & \multicolumn{5}{|c|}{ Chemical composition, \% } & \multicolumn{2}{c|}{ Blaine } & \multicolumn{2}{c|}{ fcm, $\mathrm{MPa}$} \\
\cline { 3 - 10 } & & $\mathrm{SiO}_{2}$ & $\mathrm{CaO}$ & $\mathrm{MgO}$ & $\mathrm{Fe}_{2} \mathrm{O}_{3}$ & $\mathrm{Al}_{2} \mathrm{O}_{3}$ & $\mathrm{~cm} 2 / \mathrm{g}$ & $\mathrm{R}_{2}$ & $\mathrm{R}_{28}$ \\
\hline 1 & \multirow{2}{*}{ CEM I 42,5R } & 19,84 & 63,2 & 2,08 & 2,72 & 4,65 & 4086 & 32,0 & 53,0 \\
\hline
\end{tabular}

Table 2. Basic properties of metakaolin.

\begin{tabular}{|c|c|c|c|c|c|c|c|c|c|}
\hline \multirow{2}{*}{ Lp. } & \multirow{2}{*}{ Addition } & \multicolumn{9}{|c|}{ Chemical composition, \% } \\
\cline { 3 - 9 } & & $\mathrm{Al}_{2} \mathrm{O}_{3}$ & $\mathrm{Fe}_{2} \mathrm{O}_{3}$ & $\mathrm{TiO}_{2}$ & $\mathrm{SiO}_{2}$ & $\mathrm{MgO}$ & $\mathrm{K}_{2} \mathrm{O}$ & $\mathrm{CaO}$ & Specific surface, [m2/g] \\
\hline 1 & Metakaolin & 41,9 & 1,1 & 1,8 & 52,9 & 0,18 & 0,8 & 0,1 & 13,3 \\
\hline
\end{tabular}

The planned laboratory tests included the execution of four series of concrete mixtures with the composition given in table 3 . 
Table 3. Compositions of concrete mixes.

\begin{tabular}{|l|l|l|l|l|}
\hline $\begin{array}{c}\text { Components of } \\
\text { concrete } \\
{[\mathrm{kg} / \mathrm{m} 3]}\end{array}$ & $\begin{array}{c}\text { Reference } \\
\text { concrete } \\
\text { ident. } \\
\text { (SW) }\end{array}$ & $\begin{array}{c}\text { Concrete mix with } \\
\text { the addition of } \\
10 \% \text { metakaolin, } \\
\text { ident. 10\% }\end{array}$ & $\begin{array}{c}\text { Concrete mix with } \\
\text { the addition of } \\
20 \% \text { metakaolin, } \\
\text { ident. 20\% }\end{array}$ & $\begin{array}{c}\text { Concrete mix with } \\
\text { the addition of } \\
30 \% \text { metakaolin, } \\
\text { ident. 30\% }\end{array}$ \\
\hline cement & 425 & 382,5 & 340 & 297,5 \\
\hline water & 173 & 173 & 173 & 173 \\
\hline sand & 526 & 526 & 526 & 526 \\
\hline dolomite $4 / 8$ & 467 & 467 & 467 & 467 \\
\hline dolomite $8 / 16$ & 743 & 743 & 743 & 743 \\
\hline matakaolin & ---- & 42,5 & 85 & 127,5 \\
\hline $\begin{array}{l}\text { plastisizing } \\
\text { admixture }\end{array}$ & 1,02 & 1,07 & 1,14 & 1,2 \\
\hline
\end{tabular}

The plasticizing admixture CX ISOFLOW 755 was used in the tests. It complies with the EN 934-2: $2009+\mathrm{A} 1: 2012$ standard [12]. It is a highly liquefying admixture that is used to make concretes of even high strength. Concrete mix with admixture is characterized by a long period of consistency maintenance. An admixture should be used in an amount of 0.2 to $3 \%$ in relation to the cement mass. The admixture in the tests was dosed into a wet concrete mix.

Compressive strength was determined after 14, 28, 56 and 90 days of maturation. The laboratory test was performed cubic samples with a side of $15 \mathrm{~cm}$. The samples matured in water at a temperature of $+18^{\circ} \mathrm{C} \pm 2^{\circ} \mathrm{C}$ throughout the aging period. Compressive strength was tested once on at least three samples. The final result is the average of the measurements received.

Capillary pull was tested on at least three samples from each series. Samples were formed in the air at $+18^{\circ} \mathrm{C}$ after the first 24 hours. The samples were then demoulded and placed on the first 7 days in water at $+18^{\circ} \mathrm{C}$. The next $20,48,80$ days of the samples were stored in airdry conditions at $+18^{\circ} \mathrm{C}$. After $28,56,90$ days of maturation, the samples were placed in a climate chamber and dried to a constant mass. The temperature in the air-conditioning chamber was raised gradually until the temperature reached $+105^{\circ} \mathrm{C}$. After removal from the chamber, the samples were insulated on the sides to prevent uncontrolled moisture exchange from the environment. All samples were identically protected. The capillary rising test consisted of placing the insulated samples in containers with water on plastic grids. The capillary rising test measures the mass changes of the samples, which were tested with an accuracy of $0.01 \mathrm{~g}$. The test was terminated after obtaining two identical measurements.

The absorbability test was performed on cubic samples with a side of $15 \mathrm{~cm}$. After forming the sample for the first 24 days, they ripened in forms in an air-dry environment at $+18^{\circ} \mathrm{C}$. Samples after demoulding ripened for a period of 7 days in water at $+18^{\circ} \mathrm{C}$. Subsequent 20 , 48,80 days samples were matured in an air-dry environment at $+18^{\circ} \mathrm{C} \pm 2^{\circ} \mathrm{C}$. After this time, the samples were placed in an air-conditioning chamber where they were dried to constant weight at $+105^{\circ} \mathrm{C}$. The samples were placed in a container with water to half the height of the samples for the first $24 \mathrm{~h}$. In the following days, the samples were completely filled with water up to a height of $+1 \mathrm{~cm}$ above the surface of the samples. Samples were weighed every $24 \mathrm{~h}$. The study was discontinued after obtaining two of the same masses, $[14,15,16,17]$. 


\section{Research results analysis}

Compressive strength was tested in accordance with PN-EN 206-1:2014 [1]. The cubic samples, $15 \mathrm{~cm}$ in side, were formed in water at a temperature of $+18^{\circ} \mathrm{C}$ throughout the whole ripening period. Compressive strength was tested after 14, 28, 56, 90 days.

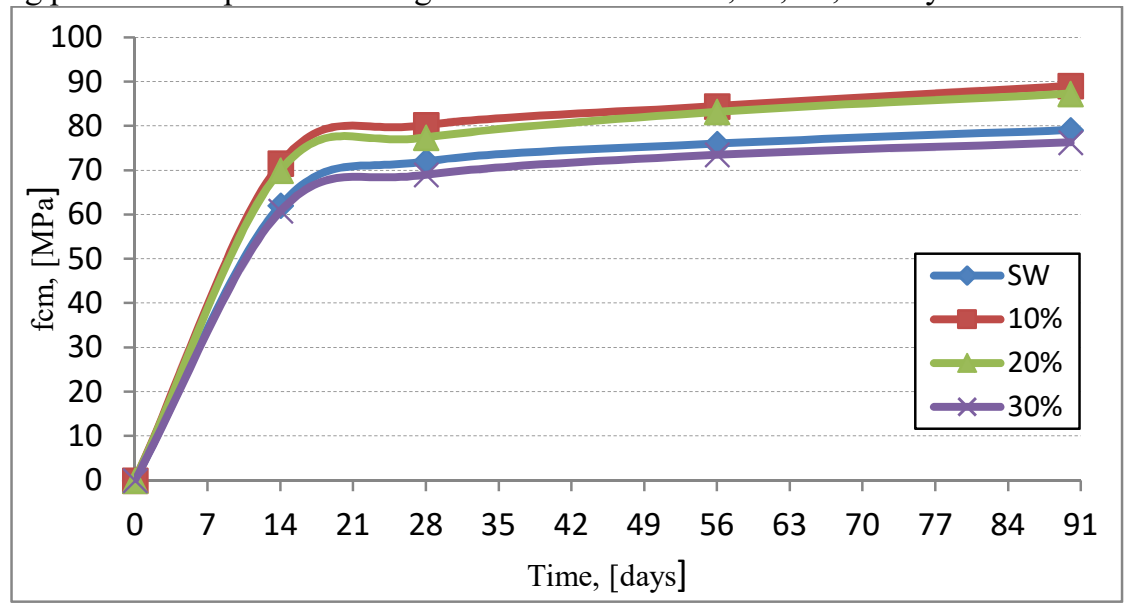

Fig.1. The increase in compressive strength of concrete.

From the analysis of the obtained results, it can be noticed that the highest increase in compressive strength was achieved by concrete with the addition of metakaolin in the amount of $10 \%$ (ident. $10 \%$ ). Its compressive strength after 90 days is $90,1 \mathrm{MPa}$. Concrete with $20 \%$ metakaolin addition has a similar increase in compressive strength to a series with $10 \%$ metakaolin. Replacement of cement with metakaolin in the amount of $10 \%$ and $20 \%$ results in similar strength increases, higher than the reference concrete in the 90th day of puberty, by an average of $12.2 \%$. The lowest strength was recorded for concrete with the addition of $30 \%$ metakaolin, whose strength at 90 days of maturation was $76.3 \mathrm{MPa}$. The reference concrete obtained compressive strength after 90 days of maturation of $79.1 \mathrm{MPa}$, lower by 11 MPa than the series with the addition of $10 \%$ metakaolin. The higher compressive strength after prolonged maturation is due to the pozzolanic reaction. The optimal amount of the additive for concrete mixes replacing the cement is from $10 \%$ to $20 \%$.

The absorbability test was carried out in accordance with PN-88/B-06250 [17] $15 \mathrm{~cm}$ cubes were used for the tests. The water absorption was tested 28, 56 and 90 days after the samples were formed. 


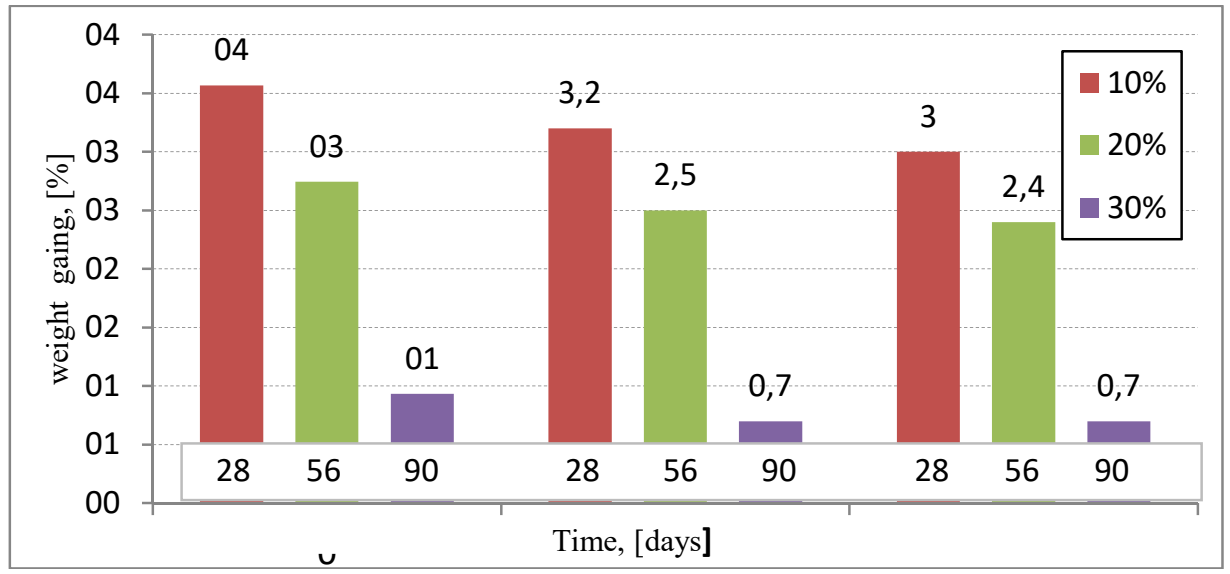

Fig. 2. Weight increase of the samples relative to the reference concrete in the absorbability test, [\%].

In the absorbability test, the highest absorption compared to the reference concrete was demonstrated by concrete with the addition of $10 \%$ metakaolin. A significant decrease in weight gain can be seen for concrete with $30 \%$ metakaolin. It can be noticed that the greater the amount of cement replaced with the metakaolin addition, the smaller the weight gain in the water absorption test. Extending the maturing time of concrete samples has a positive effect on reducing the weight gain. Comparing the maturing times, the largest increase in weight was recorded for all examined series on the 28th day of puberty. The absorbability of the tested series meets the requirements set by the Regulation of the Minister of Transport and Maritime Economy [18,19], where the maximum permissible absorbability is $4 \%$.

Capillary pulling was made in accordance with PN-88/B-06250 [17]. Capillary pull-up was tested 28, 56 and 90 days after the samples were formed.

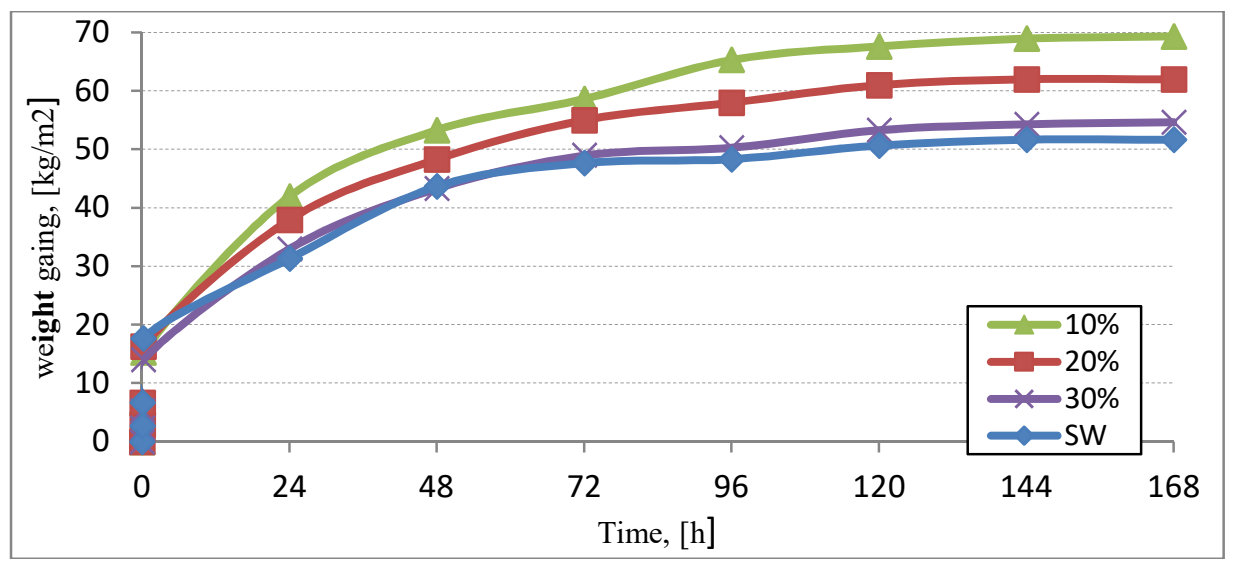

Fig. 3. Weight increase of samples in the capillary elongation test after 28 days of maturation. 


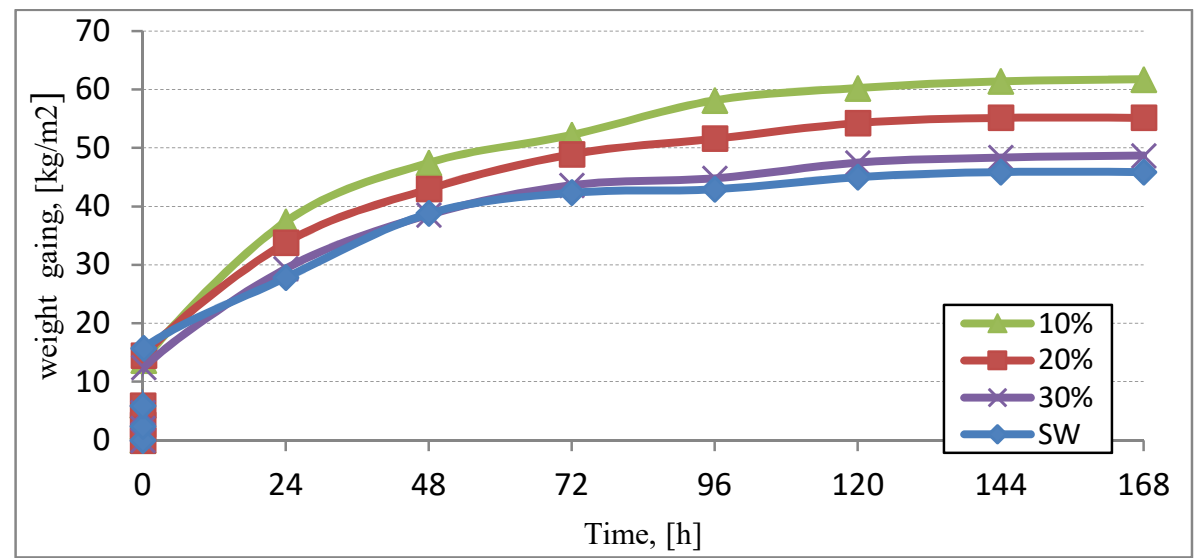

Fig. 4. Weight increase of samples in the capillary elongation test after 90 days of maturation.

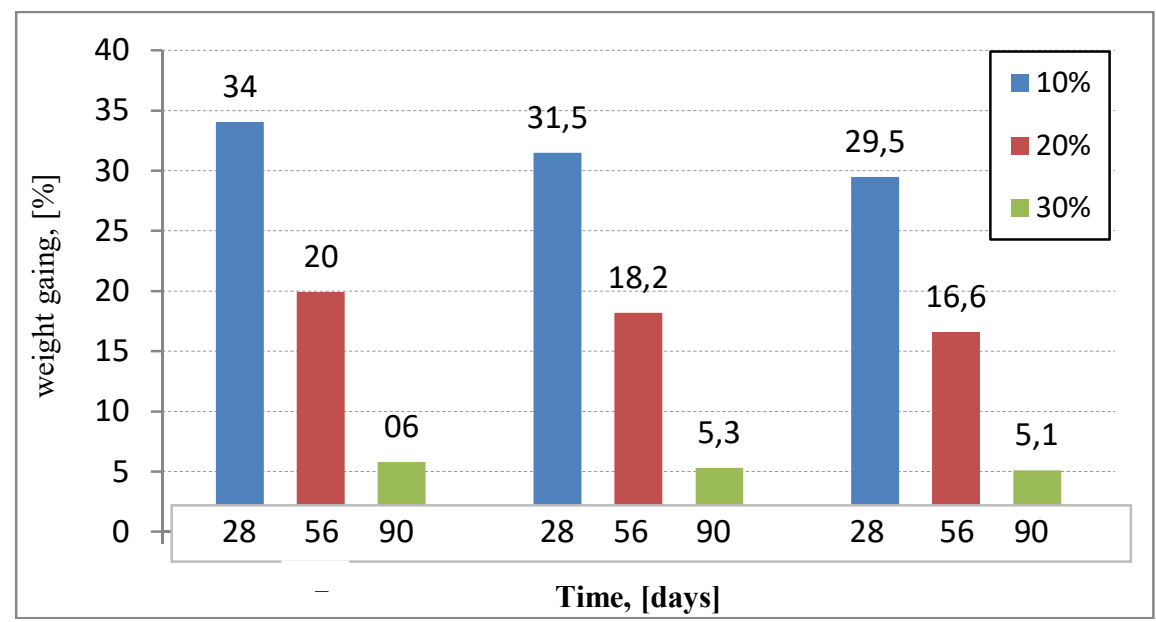

Fig. 5. Weight increase of the samples relative to the reference concrete in the capillary elongation test, [\%].

Analysis of the results indicates that the addition of metakaolin causes a significant increase in water absorption in the capillary pull of the modified series in relation to the reference concrete. The smallest increase in weight is found in concretes with the addition of $30 \%$ metakaolin. The longer the maturation time and more cement was replaced by the addition of metakaolin, the smaller the weight gain compared to the reference concrete. Analyzing the 90th day of maturation, the samples of the reference concrete and concrete with the addition of $30 \%$ metakaolin achieved comparable mass increments differing by $5.1 \%$. 


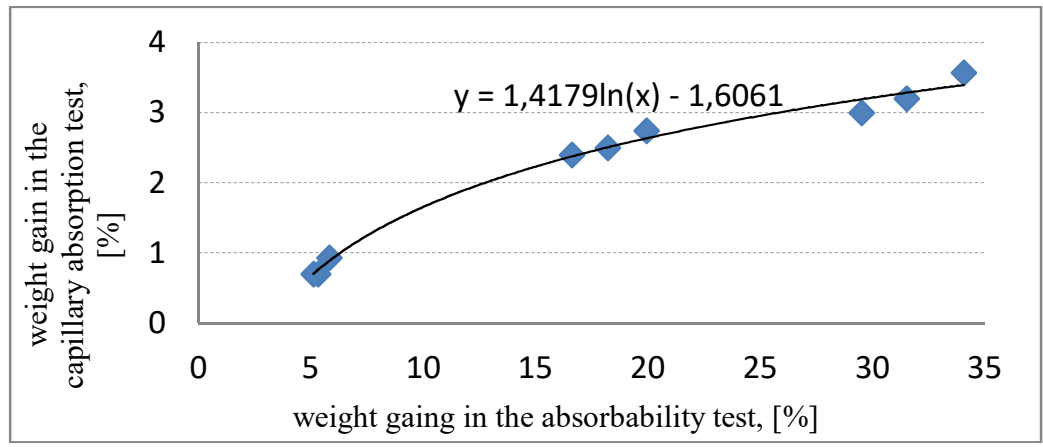

Fig. 6. Logarithmic relationship between mass increase in the absorbability test and water absorption in the capillary rising test, [\%].

Fig. 6 shows the logarithmic relationship between the concrete mass increase in the absorbability and capillary rise test. Knowing the result of one parameter, we are able to estimate the second size.

During the laboratory tests, the volume density of concrete mixtures was also determined, summarizing the results in Table 4.

Table 4. The volume density of the series tested.

\begin{tabular}{|r|l|r|}
\hline Lp. & Type of concreto mixture & Density $\left[\mathrm{kg} / \mathrm{m}^{3}\right]$ \\
\hline 1 & Ident.SW & 2340 \\
\hline 2 & Ident. $10 \%$ & 2270 \\
\hline 3 & Ident. $20 \%$ & 2210 \\
\hline 4 & Ident. $30 \%$ & 2150 \\
\hline
\end{tabular}

From the data obtained, it appears that the replacement of cement with the addition of metakaolin in a concrete mix reduces the bulk density.

A test was also carried out to determine the consistency of the concrete mix according to PN-EN 206:2014-04, maintaining the consistency of S2 for all tested series.

\section{Conclusions}

The test results provide the basis for drawing the following conclusions:

- Replacement of cement with $10 \%$ metakaolin results in an increase in compressive strength after 90 days by $12.2 \%$ compared to the reference concrete. The lowest compressive strength was recorded for concrete with the addition of $30 \%$ metakaolin. Its strength after 90 days of maturation was $76.3 \mathrm{MPa}$. The extension of the concrete maturing time has a positive effect on the compressive strength increase for all tested batches.

- In the capillary rising test, it can be seen that the highest weight gain was recorded for the series with the addition of $10 \%$ metakaolin after maturation of $69.3 \mathrm{~kg} / \mathrm{m}^{2}$ after 28 days, and after 90 days there was a drop of $61.7 \mathrm{~kg} / \mathrm{m}^{2}$.

- Absorbability after 28,56 and 90 days of maturation is lower than 5\% for all tested batches, it meets the requirements for the XF exposure class.

- The use of metakaolin in concrete mixes causes the cement matrix to seal.

- The problem with the partial replacement of cement with metakaolin is the deterioration of the workability of the concrete mix and the need for superplasticizers. The compatibility of the cement-metakaolin-chemical admixture should be considered.

- Considering economic and environmental factors, it is necessary to use a metakaolin addition in the amount of $10 \%$ to $20 \%$ for concrete mixes. The use of metakaolin as a concrete 
additive could help solve the problem of excessive $\mathrm{CO}_{2}$ emission to the atmosphere as a result of cement production [11].

\section{References}

1. PN-EN 206-1:2014 Concrete - Requirements, properties, production and compliance

2. M. Bačuvčík, I. Janotka, E.Smrčková, High - strength concrete from Portland cement with addition of metakaolin obtained of kaolin sand from deposit near Lučenec in Slovakia, Cement Wapno Beton 3, pp.187-200 (2017)

3. R. Siddique, J. Klaus, Influence of metakaolin on the properties of mortar and concrete: A review. Applied Clay Science, 43, pp.392-400 (2009)

4. D. Małaszkiewicz, Metakaolinite as a pozzolan concrete additive - review of the state of knowledge, Budownictwo i Inżynieria Środowiska 6, pp.81-94 (2015)

5. H. Changling, B. Osbaeck, E. Makovicky, Pozzolanic reaction of six principal clay minerals: activation reactivity assessments and technological effects. Cement and Concrete Research, 25 (8), pp.1691-1702 (1995)

6. M.H.Zhang, V.M.Malhotra, Characteristics of a thermally activated aluminosilicate pozzolanic material and its use in concrete. Cement and Concrete Research, 25 (8), pp.1713-1725 (1995)

7. Z. Giergiczny, Use of type II additions in concrete according to PN-EN 206:2014, Materiały Budowlane 10, pp. 110-11 (2015)

8. J. Konkol, M. Pyra, Selected properties of concretes modified with the variable share of the metakaolinite additive, Czasopismo Inżynierii Lądowej, Środowiska i Architektury, JCEEA, t. XXXI, z. 61 (3/II/14), pp.287-296 (2014)

9. F. Cassagnabère, G. Escadeillas, M. Mouret, Study of the reactivity of cement/metakaolin binders at early age for specific use in steam cured precast concrete, Construction and Building Materials, 23, pp. 775-784 (2009)

10. EN 06265:2004 National supplement to the standard PN-EN 206-1:2003

11. PN-EN 197-1:2012 Cement - Part 1: Composition, requirements and compliance criteria for common use cements

12. PN-EN 934-2+A1:2012 Admixtures for concrete, mortar and grout - Part 2: Concrete admixtures - Definitions, requirements, compliance, labeling and labeling

13. M. Dobiszewska, Concrete with the addition of mineral waste dust, Materiały Budowlane 5, pp. 63-64 (2015)

14. EN 06265:2004 National supplement to the standard PN-EN 206-1:2003

15. A. Kotwa, Properties of concrete made of cement CEM II / B-V 32,5 R and addition of mineral dust, Ekoinnowacje w materiałach i technologiach budowlanych, Monografia, Częstochowa, pp. 121-132 (2015)

16. W. Kurdowski, Cement and concrete chemistry, Association of cement producers, Kraków 2010r.

17. PN-88/B-06250 Ordinary concrete

18. Dz.U.2000.63.735 Regulation of the Minister of Transport and Maritime Economy of 30 May 2000 on technical conditions to be met by road engineering facilities and their location

19. J. Wawrzeńczyk, A. Molendowska, A. Kłak, Concrete water absorption tests, Cement Wapno Beton, 5, pp. 304-312, (2015) 